\title{
Globalization, transformation and the diffusion of management innovations*
}

\author{
Gertraude Mikl-Horke**
}

This paper suggests a shift from the discourse on transfer and transition with regard to CEE societies towards one focusing on transformation processes that come with globalization. Since globalization can be interpreted as the spread of ideas, informations, practices, goods and techniques, the perspective of the diffusion of management innovations is introduced and enlarged by including power relations, the interests of actors and cultural aspects of change. The argument of culture as barrier for the adoption of innovation is challenged in favor of one that sees it as a chance for contributing to innovation and globalization.

Dieser Beitrag schlägt eine Verlagerung der Diskussion in bezug auf die osteuropäischen Gesellschaften von der Betonung des Transfers und der Transition hin zu einem Fokus auf den mit der Globalisierung einhergehenden Transformationsprozess vor. Da Globalisierung als Verbreitung von Ideen, Informations, Praktiken, Gütern und Techniken verstanden werden kann, wird die Perspektive der Diffusion von Managementinnovationen eingeführt und durch Machtbeziehungen, die Interessen der Akteure und kulturelle Aspekte des Wandels erweitert. Anstelle der Argumentation, dass Kultur als Barriere für die Übernahme von Innovationen wirkt, wird darin vielmehr eine Chance für eigenständige Beiträge zu Innovation und Globalisierung gesehen.

Key Words: Globalization / Diffusion / Management Theories / Transition Economies / Intercultural Transfer

\footnotetext{
Manuscript received: 27.06.03, revised: 05.01.04, accepted: 12.01.04

** Gertraude Mikl-Horke, born 1944, Professor of sociology, Department of sociology, Vienna University of Economics and Business Administration (WU Wien). Research interests: Industrial sociology, sociology of work, historical sociology, history of sociology. Corresponding address: gertraude.mikl-horke@wu-wien.ac.at
} 


\section{The Changing Nature of the Enterprise}

Our era is characterized by profound changes in the ways we are guided to think about work, working life, firms, markets and states, and they spread across national borders, across societies and cultures in the wake of the process called „globalization“. In this process the Central and Eastern European (CEE) countries and the enterprises within these have very specific conditions because of their recent histories as compared with their Western counterparts. They have undergone a process of transformation from a socialist to a market system and almost simultaneously have had to cope with the globalization impact as well.

\subsection{Transfer, diffusion and institutional change}

The influence of Western principles and ideas on the transition process in CEE countries has been very strong especially on the enterprise level as Martin (1999: 150) remarks: „Western companies are a major influence on the development of CEE enterprises. They represent the major source of innovation. New technologies, new methods of production, and new products are transferred to the region by multinational corporations, both by internal transfer and through their influence on suppliers and customers in the region." Because of the EU membership aspirations especially Western European firms have functioned as models for the transition economies. But due to investment activities US influences have had great importance too. Commentators pointed also to the applicability of East Asian, especially Japanese models to the transition of CEE economies (Dickie 1991; Ross 1996). The discussion has been led under the heading of „knowledge transfer" and has resulted in a vast literature on the subject (e.g. Ardichvili, Cardozo/Gasparishvili 1998; Björkman/Ehrnrooth 1999; Cyr/Schneider 1996; Gatian/Gilbert 1996; Lyles/Salk 1996).

The transition to a market economy in Eastern Europe has involved such a process of transference of management ideas, practices and techniques to a great extent. And the studies reflect this while at the same time pointing out the difficulties encountered due to cultural barriers as will be seen below. The studies on the transfer of management principles were mostly case studies centering on joint ventures and problems encountered by foreign firms. The extent and speed of the diffusion of management innovations and business knowledge among the firms in the transition societies, however, have attracted very little attention.

At present we must acknowledge that transition as a transitory stage in the processes of change must be considered to have come to an end for most of the CEE countries by now. Moreover, the concept of ,transition“ implies a unidirectional change from one system into another which seems inadequate to describe the real processes even in the first stages of change, but which at this time must be supplanted by a conception of an open-ended transformation as 
Child/Czegledy (1996) have already demanded years ago. What happens now is a change process which is driven on by the pressures of moulding into a globalized world of business and to which enterprises all over the world have to react. The diffusion of management innovations plays an important role in this process in which also the conceptions of the enterprise as a social institution is transformed continuously. The aim of this paper is to point out that it is time to abandon the logic of transfer in favour of a focus on the spreading of new ideas making use of diffusion research albeit in a form that is appropriate for the object and the conditions in question.

Ideas as to what an enterprise is, what its goals are and how it functions, have come up in particular sociopolitical and cultural contexts, but are in their turn powerful elements shaping economic culture and the culture of society as such. This is nowhere more obvious than in the societies that have undergone the profound transition from a centrally planned economy to a system in one way or the other based on the principles of the market and of private enterprise. The change processes involved not only privatization laws, market-oriented economic policy measures and so on, but also a deep change in the way relations between people are seen, in the attitudes towards work and business transactions, in consumer behaviour, life-styles and value orientations. As Zygmunt Bauman (1993) has emphasized, the economic transition proved to cause a profound social and cultural change as well.

In the following we will look at the transition and globalization effects on enterprises in CEE countries before turning to a discussion of the diffusion of management knowledge and on the chances for innovative management and enterprise conceptions in the societies of Central and Eastern Europe.

\subsection{CEE enterprises in the transition process}

Conceptions of the enterprise have been connected closely with the ideological and political systems of regulating the economy. While economic organizations have been mere instruments to fulfill the centrally set plans of production in the socialist era of the CEE countries, with the removal of the central planning and the decisions to transform the economic system more or less along Western principles the nature of the organizations and the meaning of management had to change considerably. But this proved no smooth and direct path into a market economy as envisioned by neoclassically inspired transition theory; instead all sorts of problems came up and in consequence even humanly disastrous situations occurred (King 2001).

The literature referring to the transition to market principles in the CEE countries is vast and cannot be commented upon in this paper. A few hints must suffice to set the stage. The CEE countries concentrated at first on transforming macro-economic structures and on privatization policies. In contrast to China which has chosen a gradual change CEE economies - with the exception of 
Hungary and Romania - have ventured on a radical form of transformation, even a sort of ,shock therapy“ (Lavigne 1999: 122-3) or as Gerber/Hart (1998) put it: „More shock than therapy“. Demonopolization, liberalization of prices and privatization plunged enterprises into a completely new situation.

Enterprises in the sense of market institutions had to be created rapidly and the previously existing structures and principles had to be delegitimized while at the same time the legal and institutional framework that constitutes the basis for the market transactions was not yet fully developed. The „nature“ of enterprises has changed in ways for which the incumbent management was not prepared. Thus, the quest for management development and learning as well as for appropriate institutions and the attraction of strong shareholders (McDonald 1993) was raised.

In the meantime economic activities made headway without adequate and consistent institutional backings and policies as to regulating the restructuring and the interrelations between the organizations. This meant that enterprises had to act in a context of institutional and political uncertainty. Srubar (1994) described the anomic effects of the precipitate transition process resulting in social exclusion, disintegration and particularization. Burawoy/Krotov (1992) characterized the process not as one leading to a market economy, but to a sort of „merchant capitalism“ they saw as hindering development rather than promoting it. In a similar way Müller (1995) expressed doubts that the transition can be seen as a positive modernization of these societies, and Morawski (1998) raised demands for a realistic evaluation including also social values like solidarity and social justice.

With regard to CEE enterprises it is difficult to conceive of any one dominant „conception of control“ (Fligstein 1990) since there were several ways in which firms came into being: Some have been former state-owned enterprises which were turned into market-oriented organizations through restitution, spontaneous privatization by managers or employees, or through vouchers and sales (Martin 1999; Lavigne 1999), in which process they were in most cases split up in fragmentary units which in many cases are heavily dependent on the local sociopolitical connections (Clark 2001). Some firms have been founded anew by entrepreneurs, some have been set up as affiliates of or with the aide of foreign corporations. Foreign engagements have taken various forms from licensing and franchising over joint ventures to wholly owned subsidiaries. Thus, there exists a mixture of state-owned enterprises, privatized and reformed organizations, start-ups and foreign companies with specific features in each of the CEE countries. The actions of restructuring of the enterprises were inspired by different interests and by diverse ideas among which Western models and powerful interests of foreign investors play a great role (Shama 1995; Lyles, Carter/Baird 1996; Lyles/Salk 1996). 
Company reorganizing involved the production organization, the forms of financial control as well as the introduction of marketing functions (Marinov, Marinova/Watts 1998). The motives of managers, the interests of stakeholders and the role of organizational legacies from socialist times determined structural choices (e.g.Clark 1998) and the propensity to change (Spenner et al. 1998; Suhomlinova 1999).

Whether transition has come to an end is a controversial question and cannot be answered for all CEE countries equally in one sense or the other. While actual reforms as well as the levels of economic achievement have remained below expectations during the first years after 1989, there has occurred a great upsurge of activities and performances since the mid-90's. At the same time, however, also the process of globalization was stepped up in all advanced countries inducing major changes. Transformation, thus, is not a process restricted to „transition societies“, but is a constant challenge for all countries and enterprises anywhere in the world that try to keep up with globalization.

\subsection{The transformatory effect of globalization on enterprises and cultural change}

The discourse on globalization acquired a new relevance and meaning in the 90's following the dissolution of the Soviet Union and the transformations of the socialist economies of Eastern Europe along the lines of market principles adding political legitimation to these. However, in the common understanding of globalization economic forces are dominant and firms and businesses are in the center of the process. Even in societies that have not experienced such a radical break in continuity as the CEE countries, the change in the nature of the enterprise over the last two or three decades is so profound that it comes close to a reinvention of this social institution. The CEE societies were thrust into this new globalized and flexible world of markets and enterprises without the intermediate processes that Western countries had been undergoing.

On the level of enterprises globalization means exposal to rapid international capital flows exerting pressure to respond flexibly to shareholder interests, global investments and activities of multinational corporations and the greatly increased necessity to take in and respond swiftly to new ideas, informations and technologies. Institutional differences in the form of external rules or internalized attitudes account for the readiness and swiftness in which a firm or a society takes up new developments and is capable to get ahead in a fast changing world (Strang/Meyer 1993). The extent to which certain beliefs, values and norms favouring achievement and efficiency are internalized by managers is important for their attitude towards changes. Regulations concerning work as well as institutions of education and professionalization play a great role, but also institutional characteristics of firms can be promoting or hindering the acceptance of innovations. Institutions can act as „barriers to 
imitation“ (Lehrer 2001: 363) and, as Hollingsworth/Boyer (1997: 455) noted with regard to production systems, countries decline when they lack the capacity to mimic the most competitive institutional arrangements.

Comparative studies mostly stress the lasting differences between economic cultures (Berger/Huntington 2002) and between business systems (Whitley 1994), and highlight the embeddedness of economic processes in institutional structures (Hollingsworth/Boyer 1997; Orrù, Biggart/Hamilton 1997; Hall/Soskice 2001; Whitley 2000). According to these studies the impact of globalization does not alter domestic business systems in the direction of global unification.

However, while there still prevail unique systems of interactions between the state and the largest firms in the advanced countries, Fligstein (2001) had to admit that globalization and the shareholder-value conception of control have acquired the status of an ideology with a worldwide appeal through creating a universalized discourse that redirects ways of thinking and acting towards change inspite of persisting institutional differences. This shows the increased importance of the diffusion of ideas through discourse and rhetoric in the globalization process.

Since business operations had to be undertaken under conditions of considerable uncertainty in CEE countries, outward influences regarding business behavior and management practices are especially strong there because of the combined effects of transformation and globalization. The impact of foreign investments on the restructuring of enterprises, the adaptation to competitive markets and the internationalization strategies is great (Marinov/Marinova 1998). The motives of foreign investors determine the strategic priorities of firms (Marinov/Marinova 1999) and the types and levels of risks perceived influence the market-entry strategies of international firms (Shama 1995).

The actual transformation process in the former socialist countries took several turns and produced diverse forms of enterprises. Since at the same time also Western economies and enterprises underwent major changes in their structures and strategies, a lineal transition to any particular model of a market economy cannot be envisaged by the CEE countries, but they have to join the general transformation processes. Attention must, therefore, be diverted to the processes and forces of globalization working on the level of enterprises, and among these the diffusion of management innovations requires special notice.

\section{The Diffusion of Management Innovations}

Both transition and globalization involve the transfer and the spreading of ideas and goods, techniques and practices among firms and within and across populations. In the following we discuss briefly the perspective offered by a 
focus on diffusion in order to better understand the multifarious and dynamic processes of change. Since there is a body of literature on the diffusion of management theories and practices we will draw on these in order to gain insights into the specific concerns of diffusion studies in the field of enterpriserelated problems.

\subsection{Diffusion research and management innovations}

Modern diffusion of innovation theory invariably refers to the work of the French sociologist Gabriel Tarde who stressed imitation as the driving factor of cultural change and development (Tarde 1890). Tarde observed that inventions usually diffuse from a centre like waves and that this process is caused by social forces. Diffusion studies were then given a communication-theoretical underpinning (Katz 1960). Everett Rogers (1995) defines diffusion as the process by which an innovation is communicated through certain channels over time among the members of a social system. The spread starts with the early adopters and when more and more people take to the innovation the rate of adoption rises progressively among the population until it reaches a culminating point where the rate of new adoptions begins to decrease again. This is seen as a self-generated tendency in the social system unleashing a diffusion effect when a critical mass of adoptions becomes a threshold for further spread (Granovetter 1978). In many recent diffusion studies which have been developed mainly in rural sociology, geography, developmental economics and mass communication studies these behavioural assumptions are connected with the use of network analysis.

Diffusion of innovation research has been applied also to organizational structures, production system changes and management theories. Studies dealing with management innovations like strategic planning units, job enrichment, T-groups, matrix structures, quality circles, joint ventures, etc. have shown that there exist pressures like bandwagon effects when firms feel forced to adopt a certain innovation in order not to fall behind competitors. Local proximity or existing communication or cooperation between firms may further adoption. In many cases firms with a high reputation in the field are imitated by those with a lower one.

Firms within a field observe and imitate one another which can result in a contagious process, a "fad" Abrahamson (1991). In the case of fashions organizations imitate models promoted by fashion-setters, which are successful firms from outside the field. The „success stories“ as, for example, presented in the famous bestseller by Peters and Waterman of 1982 „In Search of Excellence“, induce imitative behaviour. Thus, when successful organizations decide on an innovation, also technically inefficient practices will tend to diffuse and old technically efficient ones will be rejected when they are abandoned by fashion-setters. According to Strang/Macy (2001) also the 
overattention to the bottom line can generate waves of innovations of which many may be worthless. The anxiety to succeed and the dread of failure causes risk-aversity and hence the tendency to „adaptive emulation“, that is, of imitating the most successful peers. Since successes are reported, failures usually not, this creates a bias which contributes to generate faddish cycles. Tolbert / Zucker (1983) argued with regard to civil service reforms that once a threshold of adoptions is reached, this lends a sort of legitimacy of its own to the innovation leading to further diffusion. They noticed also that early adopters modify practices or techniques according to their needs, whereas later on conformity to standardized practices prevails.

In the last decades the speed with which new management theories and techniques have appeared and disappeared has accelerated a good deal and many conceptions of management have diffused on a large scale to companies all over the world. Many of the innovations were replaced soon by new practices causing disruptive effects on the organization or on business proceedings. Since this behaviour towards innovations has been observed in many cases, diffusion studies came to the conclusion that adoption decisions in management are based to a considerable degree on contagious processes and not on rational decision-making. Managers priding themselves on their rationality, thus, turn into docile followers of creeds or as Strang / Meyer (1993: 506) put it: "The modern actors whose uniqueness and autonomy are most celebrated are precisely those most subject to the homogenizing effects of diffusion".

\subsection{Some problems of the diffusion of management innovations in CEE societies}

In CEE societies managers and firms experienced direct influences from foreign partners or the actions of multinationals. This has been reported in particular case studies of individual firms (e.g. Lyles / Salk 1996), but there are few hints as to the wider spreading of innovations. Foreign companies or partners in joint ventures have certainly played an important role also as models or as fashionsetters, and most probably there were also faddish elements in the process of reorganization.

However, with regard to the question of rationality, it can be assumed that Western firms' strategies and decisions have followed efficiency criteria according to the predominant neoliberal conceptions or have been determined by strategic guidelines put forward by their headquarters. In these decisions, it is true, there may be also irrational elements exactly because of the preoccupation with performance. Observations of others and imitation of success stories can be assumed to play a special role in newly established transplants in different local contexts. The lack of understanding of the local conditions by foreign managers (Edwards / Lee 1999) may contribute to this since uncertainty is great and the pressure to succeed high, so that managers 
look for models promising good results. For indigenous managers, on the other hand, imitating Western models is often the only way open for them, at least, before sufficient experiences have been made to make more discriminating decisions. Thus, imitation may be considered at least a formally rational strategy under these conditions of uncertainty. Even if a technique or principle does not look promising in the way of improving performance, adopting it may nonetheless have positive effects, since signalling innovativeness can boost performance indirectly by improving the motivation of workers and the evaluation of customers, thus, producing symbolical or emotional efficiency. The wish to appear innovative and modern is very often a cause leading to imitative behaviour and is especially pronounced where seemingly more advanced models exist elsewhere, which is the case in CEE societies. Cole challenges the notion that fads are just ,ritualistic copying“"(Cole 1999: 13) on the basis of understanding imitation as a creative learning process through trial and error. He views fads not as capricious behaviour but as „,building blocks“ (235) with the potential for developing a new orientation on a larger scale. This is a perspective which seems to hold much relevance for management in the process of transformation at a fast pace.

Management innovations can be many things, they may be principles, practices, organizational designs, theories of leadership, even quasi-philosophical conceptions like the recent „Six Sigma“ principle. Taking over the rhetoric of a new managerial philosophy is something quite different from the "entrenchment" of a practice or a structural design in the organization. For the adoption of the rhetoric a faddish process may be responsible, but the implementation of the innovation involves quite different aspects of institutional and cultural dimensions. Of course, it must be noted that already the use of a certain rhetoric can create a new situation by gradually redirecting the ways of thinking and the behaviour of people, a process which applies especially to the ubiquitous discourse on "globalization“ that induces a certain perception of reality followed by respective actions, and thus results in constructing a new reality of facts.

There are very few studies on diffusion with regard to CEE enterprises, one being by Malone/Kirk (2000) who investigated the adoption of lean production, total quality management and benchmarking in Polish manufacturing companies, and another one by Warhurst (2000) on the diffusion of soft technologies from multinationals to indigeneous firms. The reason why diffusion studies on the adoptive spread of managerial innovations in CEE societies are rare, may be their emphasis on fads and fashions which seems somewhat frivolous in these cases. The more important fact is, however, that actually there has been transfer, but little spread. Diffusion of management principles seems to be restricted to mostly foreign companies or joint ventures. There are barriers to the spreading of knowledge because of competitive reasons and there are probably also hindrances deriving from cultural and psychological 
facts. Diffusion of knowledge can be impeded by raising resentments when, for example, foreign managers show a low estimation of their local partners (Lenke/Goronwy 1996). Especially in cooperative ventures with foreign partners the way power and control is shared between the partners is essential for motivation and hence for learning (Cyr 1997).

Diffusion happens not only through intentional acts of transfer, but also in the course of business transactions as such; in this sense Bennett (1996) saw doing business as the best way of management development in CEE countries. But innovations spread not only through communication, power relations, informal networks and economic interests play a great role in diffusion. In CEE societies foreign investors and business partners are transmitters and promoters of management innovations and wield considerable power. The emphasis of diffusion research on contagious processes means that questions of power and legitimacy and the interests and strategies of actors are given too little attention.

\subsection{Diffusion through power relations and informal networks}

In the spread of management innovations networks and the loose contacts between individuals belonging to different groups or cliques which have been found of special importance to the spreading of informations (Granovetter 1973) play a great role. The greater the number of networks in which an organization is involved, the greater the likelihood of gaining access to innovations. But networks can also work to inhibit the spread of innovations. Traditional patterns of interfirm relations, established conceptions of management and professional outlooks can influence the diffusion process which was shown in a comparison between the UK and Sweden (Swan, Newell/Robertson 1999) but applies as well to CEE countries (Frege/Taplin 1999; Morawski 1998). The transition process has not uniformly resulted in the disappearance of old connections which have persisted inspite of the changes in organizations (Grabher/Stark 1997).

The network relations that have survived from socialist times, are mostly informal relations as Whitley et al. (1996) showed with regard to interfirm relations between ten large enterprises in Hungary or Clarke (1995) for Russia. They run across companies, authorities and political circles. Informal personalized contacts play a great role in the CEE countries partly because of the persistence of socialist cultural elements, partly because of the weakness of institutional and relational structures of the new system. These informal network relations have to be considered in the transformation process as well as with regard to introducing and spreading innovations. Although Ledeneva (1997) pointed out that the socialist tradition of „blat", the use of informal contacts and networks for obtaining privileges and scarce goods, has changed since then, there still exist strong traditions of network relations and personalized contacts that have an impact on the way enterprises function and 
innovations are taken up. In most cases these social remnants of socialist times are seen as hindering innovations. Jankowicz (2001) argues that the informal relations and networks which exist since socialist times should not be seen as a mark for the inadequacies of the pre-1989 management practices, because they reflect the ability for adaptive adjustment to the then existing conditions. Very often the informal relations between the people involved are more important for the diffusion of innovations than the formal contractual ones. They should instead be seen as skills which can be used also for effective performance in the new market situations. Moreover, ignorance of these capacities often leads to misunderstandings by foreign partners and hence to ineffective change interventions.

Social structural aspects play a great role in the diffusion of management innovations, and they involve power and authority relations, dependency and inequality. This is especially the case when firms are tied to one another by directorships, strategic alliances and financial links or are connected through customer/supplier relations. Enterprise groups related through financial, personal or functional ties are, of course, also networks in which informations circulate, however, in many cases not through cohesive communication, but through power relations. Intercorporate relations and interlocking directorates function as channels in the diffusion process.

The opening up of the CEE economies for foreign contacts, investments and activities has added further and quite different kinds of network relations based on financial links, venture connections and relations between foreign and local firms with intercultural aspects within firms and across firms. Often supply chains function as media for the diffusion of „soft technologies“ like management principles and techniques from multinational corporations to indigeneous firms (Warhurst 2000: 30-31).

The networks that play a role in the diffusion of management innovations encompass also consulting firms, business schools and business media.Ginsberg/Abrahamson (1991) have called them „fashion-setting networks" dedicated to the creation and dissemination of management innovations. Each of these actors plays a different role, but they all have an interest in the transmission and popularization of ideas on management and business. The state or the national governments must be taken into consideration, too, especially in transition societies because of the tradition of state planning and intervention and, hence, the widespread reliance on the authorities to promote or enable transformation and because of the traditional intermingling of economic and political relations. Martin remarks on the lingering specificity of the transition societies in Central Eastern Europe: „Three specific features distinguish post-socialist CEE from competitive capitalism: the frequent absence of ,real owners' of capital; the ubiquity of networks; and the continuing role of the state." (1999: 175) 
The various groupings of actors form structures of interrelated networks. Abrahamson/Fombrun (1992) distinguish four overlapping sectors: the network of mass-media organizations, the network of educational organizations, the network of governmental organizations and the network of business organizations. In their study they investigated the effects of the relations that run across these networks, i.e. of the interorganizational networks, on the production of macro-culture even without the actors following outright strategic goals. But of course interests in the diffusion of ideas and technologies must not be disregarded, since the interfaces between the interorganizational networks can be used effectively in order to launch strategies benefitting some actors.

\subsection{Interests and actors in the market for diffusion of management innovations}

Diffusion theory has unilaterally looked at the adoption side, but actually the side of promotion must be taken into the picture as well. Diffusion is a twosided process with the promoters or "suppliers" on one side, and the „consumers" of business innovations on the other side. Using this market perspective, however, does not mean that markets are understood in the sense of neoclassical economic theory. They are defined as social structures and political processes between actors that have diverging interests. This makes use of the view of Granovetter (1985) who insisted that economic interactions are centered in social relations and hence, that markets are embedded in network relations. Similarly, Fligstein (1996) has suggested a view of „markets as politics“ to indicate that the social structures of markets come into existence, produce stable situations and are transformed again, and they do this with the backing of the modern state that created the institutional conditions for markets, that is, property rights, governance structures, conceptions of control and rules of exchange. The market process is seen as a struggle of powerful actors conducted within firms in order to control organizations and across them in order to control markets.

On the level of management innovations the state usually does not play a direct role, but other actors with profit interests in the diffusion process as such have come up in a big way over the last decades: the consulting industry, the business media, business schools, and other suppliers or transmitters of management knowledge which have been termed ,management-knowledge industry“ (Kipping/Engwall 2002). This industry works closely together with academic circles, socalled management gurus, with mass media and the educational system as such (Micklethwait/Wooldridge 1997: 50). Their „products“ are ideas, principles and techniques of how a firm or a work organization should be run. The actors in the knowledge industry constantly look for new „management fashion niches“ (Kipping/Engwall 2002: 712) to be exploited and the industry has grown considerably as a consequence. Kieser (2002) perceives an explosion of consulting markets and stresses the creation of 
demand by launching fashions and manipulating adopters. This involves the commodification of management concepts, that is, problems and solutions are transformed and packaged into standardized recipes that can become a marketable product.

The CEE societies with their great demand for management knowledge and business education are an important area of expansion of this industry and a large market for the diffusion of innovations in business and management. The products offered by the knowledge entrepreneurs in CEE countries encompasses consulting on change management, management development and education, cross-cultural training as well as with regard to specific tools and techniques (Walger 1997; Holden 2000; Villinger 1996).

The development of management has been seen to be of great importance for the catching up of CEE economies (Gatian/Gilbert 1996; Vlachoutsicos/Lawrence 1996). This demand, however, is not met yet by the official curricula of the state schools (Bennett 1996), and learning by doing, that is, through the cooperation with a foreign partner or the employment in an international firm (Soulsby/Clark 1996) cannot prove sufficient. Therefore, management formation has become one of the booming industries in CEE countries (Edwards/Lee 1999). Universities offer management courses as a side track and private business schools have been set up by copying the curricula of Western business studies. There are also cooperations with educational institutions in Western Europe or in America in the field of management studies (Tóth 1995; Burke/Peterson 1997), and international agencies promoted business and management education for both ideological and practical reasons (Lupton/Jansen 1998).

\section{Global Transformation and Cultural Change}

The zeal with which Western ideas have been diffused in Eastern Europe may at least from the viewpoint of East European commentators - disclose a missionary quality. Some commentators have seen a veritable „management crusade" to bring Western economic culture to Eastern Europe (Jankowicz 1994; Kostera 1996). Not only interests, but also ideologies and their value bases have been involved on behalf of Western knowledge providers and investors especially in the first phase of transition.

One could assume that this zeal would find a receptive field of diffusion where former conceptions of organizing and behaving are delegitimized. But certain value orientations and attitudes that were shaped in the times of the socialist system have persisted on the side of managers and workers especially in the privatized former socialist establishments, but also among consumers. As Robinson/Stepien state, ,it would be simplistic to underestimate the strength and pervasiveness of the socialist culture" (Robinson/Stepien 2000: 133). 


\subsection{Culture and performance}

Studies of management and business in CEE countries show a strong performance-orientation and changes are evaluated with regard to their results in terms of performance improvement and efficiency gains. Most of the studies take the perspective of the foreign investor and ask for the causes of poor performance and efficiency inspite of the introduction of Western styles of management and organizational structures (e.g. Nasierowski 1996; Riff 1994). Especially the cases of obstacles to good performance in joint ventures have received wide attention. In many studies it has been shown that the introduction of reward systems based on performance or other managerial devices which prove effective in Western contexts encounter difficulties in Eastern Europe (Mueller/Clark 1998; Fey, Nordahl/Zatterstrom 1999). A particular concern is the introduction of human resource management in the case of foreign acquisitions and joint ventures (Cyr/Schneider 1996; Meschi/Roger 1994). Many studies have commented upon the attitudes of managers and workers towards changes in the enterprise and the work organization (Svejnar 1996; Ilieva 1999). A study in a former state-owned enterprise in Poland which had been bought by a multinational firm has shown that organizational restructuring making use of change agents and the redeployment of key persons had to be complemented by the dissemination of new cultural values and norms as well (Robinson 1999).

Among the former state-owned enterprises the diffusion of modern organizational structures and management practices seems to be still limited even in the fast developing CEE societies, especially, where ownership lies in the hands of insiders or the state. There changes have not been conspicuous even when formal restructuring had been introduced (Lizal, Singer/Svejnar 1994). Still hierarchical relations and top-down lines of communication persist and make the integration of the creativity and responsibility of the lower levels of organizations difficult (Lorentzen 1998). Whitley/Czaban (1998) by investigating 27 Hungarian enterprises in the early 1990s came to the conclusion that even ownership changes have not always led to major shifts in control. Private owners implemented no sharply different policies from state managers before. Other studies report that real changes happened only in start up firms or in those companies who cooperated with an international partner (Savitt 1998). Even in cases of partnerships with foreign firms, however, it has been shown that techniques and practices were taken over, whereas strategies did not change in a similarly rapid way (Konecki 1997; Lyles, Carter/Baird 1996).

Cultural factors have been held responsible for these „limits of knowledge transfer" (Jankowicz 2001). It was argued repeatedly that the "old" cultural mind frames cause a cultural lag which inhibits the change of structures and behaviour (Kostera/Wicha 1996; Pribova/Savitt 1995) and causes inefficient 
management practices to persist (Vamosi 2001). Also these cultural factors cause differences in structure and performance beyond the effects of the diversity of policy measures and of concrete situations in the individual societies and firms (e.g. Luthans, Patrick/Luthans 1995; Mense-Petermann 1997).

Some commentators have perceived even a clash of corporate cultures hindering management development and actual performance (Thomas 1999; Roney 1997). Mentality differences have been seen responsible for the communicative difficulties encountered by Western managers (Tóth 1995), but also the ethnocentric approach on behalf of foreign executives disregarding the vulnerability of social identities of indigeneous managers by colonialist attitudes and the exertion of power and control have been observed (Lenke/Goronwy 1996). Therefore, the importance of understanding the views and situations of the indigeneous managers, employees and consumers as well as that of the representatives of the state on behalf of foreign executives and managers is recognized (Gatian/Gilbert 1996).

But still most studies point to the persistence of attitudes and ideas from socialist times and their interplay with management decisions (Frege/Taplin 1999). These are found in the field of managing and working as well as with regard to consumer behaviour so that the relevance of the introduction of marketing expertise rooted in the Western capitalism for the transition economies has been challenged (Thomas 1994). Neither the attitudes of workers nor the behaviour of consumers seemed then to foster the development of market orientation. It has been noted (Bauman 1993) that the image of Western economies as affluent consumer societies had led to paradoxical and detrimental aspirations and reactions in the first phase of transformation. Lovell,Ledeneva/Rogachevskii (2000) in their interdisciplinary study have shown the deep-seated and long-lasting tradition of bribery and „blat“, the informal exchange of favours, in Russia which must not be underestimated as peripheric phenomena but as deeply entrenched facets of social relations.

Sztompka (1993) even perceived a ,civilizational incompetence“ in postcommunist societies caused by the deep cultural legacy inherited both from the pre-modern past and the fake modernity of real socialism and resulting in deficiencies in entrepreneurial culture, political culture, discourse culture and everyday culture. He argues also that these societies lack trust as a vital resource necessary especially for the transition to a market economy, instead he finds a culture of distrust pervading all levels of social life (Sztompka 1995: 254).

\subsection{Culture as an asset in global transformation}

Ideas shape the view people have about reality and their diffusion involves an interpretative and cultural sense-constructing process (Alvarez 1998) which in 
the case of enterprises means the way how managers perceive their firm, their work, the organization and their own roles (Kostera 1995). Management theories are developed within certain cultural contexts and they acquire a culturally differentiated importance in countries into which they are introduced (Hofstede 1994).

In our globalized world of today ideas of work, management, business and markets are influenced on one side by the spread of the business ideology of global neoliberalism and on the other side by the social and cultural traditions in the local context (Ralston et al. 1995). These contradictory influences cause problems in enterprises when innovations are to be implemented involving reorganizing labor processes and social relations in the workplace (Kovach 1994/5; Ardichvili, Cardozo/Gasparishvili 1998; Björkman/Ehrnrooth 1999). In a case study in Romania Heintz (2002) found that the cultural background of employees can render management innovations useless when they are not taken into consideration.

The process of implementation involves the change of deeper-seated aspects of breaking routines, changing value conceptions and attitudes and, hence, effects the existing relations and social structures profoundly. Implementing a new technique or practice means connecting it with the cultural and institutional structures and traditions which have produced the attitudes and perceptions of people. For entrenchment a practice must fit into all aspects of the organization as well as into the wider context, there are connections with cognitive structures and deeply held values to be considered, as well as attitudes and behavioural patterns (Zeitz, Mittal/McAulay 1999). This means, however, that by implementing it we are changing the innovation itself, too, because we make use of the tacit knowledge of people and the conditions provided by the local situation.

Culture is the values and attitudes of people, but encompasses also the reservoir of knowledge, the traditions and knowhows existing in a society which can serve as the basis for creating something new. The potential contributions of the local managers and employees in furthering transformation and producing innovations, therefore, is an important resource which must be recognized. This implies a shift from the preoccupation with catching up in terms of efficiency and performance indicators towards a perspective directed at producing innovations (Makó 2001). For this shift the CEE societies must turn to a certain extent to their own traditions and interpret them anew as to the valuable elements contained in them that should not be shed undiscriminately. The practical knowledge guiding everyday actions is embedded in the forms of living and ways of thinking, is incorporated in routines and tacit knowledge. It must be recognized that the transition societies also possess a reservoir of experiences that must not only be judged as barriers to modernization, but can in their turn contribute positively to economic culture by knowledge sharing for 
reciprocal enrichment. Especially, when it comes to entrenchment, the diffusion of innovations turns into a process of adaptive learning involving specific development paths.

The argument of culture as barrier to change and diffusion of innovation, therefore, should not be overrated. The reasons for poor economic performance lie in many cases elsewhere and the cultural argument serves as excuse. Although cultural aspects are of a pervasive and profound importance in all aspects of life, they are not stable substances, but change with our situations and actions continuously. The discourse on culture, however, tends to treat it as if culture were a stable entity and thus, supports the perception of culturally differentiated worlds of understanding and acting. But culture is constantly produced through acting in everyday life as well as through the ideas and informations that are diffused. At present ideas originating in the sphere of business and the economy like the concept of "globalization" itself have a great impact on our perception of the world, mixing with our acqired ways of thinking and acting to produce diverse meanings.

Globalization is a process of diffusion on a worldwide basis, but it can also be seen as the innovation that is spreading in its own right. The enterprises of the world can be divided, therefore, according to their swiftness to take to globalization as a strategy, that is, into early and late globalizers (Mathews 2002). The CEE firms are relative newcomers, also because they have concentrated so far on the transforming and restructuring of their organizations and conceptions of management in order to achieve efficiency levels that can compare with their Western counterparts. The changes in the CEE countries are instances of the transformations going on in the process of globalization in general.

Transformation due to globalization is going on in all countries today by which new forms, structures and meanings are created. In this process networks, interests and strategies of actors as well as attitudes and perceptions play a role, all of them shaping and being shaped by culture. Culture involves power aspects and questions of legitimacy. Cultures and societies all over the world are influenced by the global activities of the multinational corporations and by transnational networks, the movements of global capital and the spread of ideas through worldwide nets of telecommunication, in the field of enterprises also by the management knowledge industry. But on the other hand the ideas change in the course of their spreading and the techniques are transformed in the process of implementation in the local contexts. Also the CEE societies, therefore, are not just recipients of the transfer of knowledge, but hold a potential for contributing from their side to the furthering of knowledge. In this sense the time has come to recognize the diversity between the CEE societies in a positive way, that is, as different paths of transformation, not to a uniform market 
society, but as ongoing open-ended processes of specific developments (Luthans, Patrick/Luthans 1995; Mense-Petermann 1997).

\section{Conclusion}

The discourses on knowledge transfer and transition to market economy gradually become outdated at least with regard to some of the CEE societies. These societies transform as they get integrated more and more in the globalized world. Innovations are taken up in this process leading to changes of rhetoric and/or restructuring and reorientations of enterprises. We have put forward a view of diffusion as a process not restricted to a faddish conception of adoption behaviour nor to a unilateral transfer perspective, but as a realistic consideration of the forces leading to development of knowledge and enterprise performance. In this process power and influence, network relations and social structural aspects play a role, but diffusion as a two-sided affair implies also the intermingling of old and new, of outside influences and inside perspectives. Old and new informal networks between managers and with other actors in the political and social context, the power and motives of investors, the structure and strategies of multinationals and the policies of the state must be taken into consideration as well as the attitudes and the tacit knowledge of managers, workers and consumers. Thus, diffusion must be seen as a complex process of spreading and implementing, in the course of which the innovation itself undergoes changes. Culture, which has been viewed mainly as a barrier to the transfer of knowledge and the performance from the viewpoint of foreign investors, holds a potential for innovation and a chance for reciprocal enrichment.

\section{References}

Abrahamson, E. (1991): Managerial Fads and Fashions: The Diffusion and Rejection of Innovations, in: Academy of Management Review 16, 586-612

Abrahamson, E. (1996): Management Fashion, in: Academy of Management Review 21, 254285

Abrahamson, E./Fairchild, G. (1992): Management Fashion: Lifcycles, Triggers, and Collective Learning Processes, Administrative Science Quarterly 44, 708-740

Abrahamson, E./ Fombrun, C.J. (1992): Forging the Iron Cage: Interorganizational Networks and the Production of Macro-Culture, Journal of Management Studies 29, 175-194

Alvarez, J.L. (1998): The Sociological Tradition and the Spread and Institutionalization of Knowledge for Action, in: Alvarez, J.L. (ed.): The Diffusion and Consumption of Business Knowledge, New York, 13-57

Ardichvili, A./Cardozo R.N./Gasparishvili, A. (1998): Leadership Styles and Management Practices of Russian Entrepreneurs: Implications for the Transferability of Western HRD Interventions, in: Human Resource Development Quarterly 9/2, 145-155 
Balcerowicz, L. (1995): Socialism, Capitalism, Transformation, Budapest

Bartlett, C./Goshal, S. (1989): Managing Across Borders,, London

Bauman, Z. (1993): Auf der Suche nach der postkommunistischen Gesellschaft - das Beispiel Polen, in: Soziale Welt 44/2, 157-176

Bennett, D.R. (1996): The Stalled Revolution: Business Education in Eastern Europe, in: Business Horizons 39/1, 23-29

Berger, P.L./Huntington, S.P. (eds.) (2002): Many Globalizations. Cultural Diversity in the Contemporary World, Oxford

Björkman, I./Ehrnrooth, M. (1999): HRM in Western Subsidiaries in Russia and Poland, in: Journal of East-West Business 5/3, 63-80

Burawoy, M./Krotov, P. (1992): The Soviet Transition from Socialism to Capitalism, in: American Sociological Review 57/1, 16-38

Burke, R.J./Peterson, R. (1997): Economic Transformation in Central and Eastern Europe: Effects of a Western Initiative, in: Journal of East-West Business 3/4, 59-71

Child, J./Czegledy, A.P. (1996): Managerial Learning in the Transformation of Eastern Europe: Some Key Issues, in: Organization Studies 17/2, 167-180

Clark, E. (1998): Czech Enterprises and the Multidivisional Form: Legitimation, Legacies and Structural Choice, in: Journal for East European Management Studies 3/1, 46-63

Clark, E. (2001): Enterprise Fragmentation in the Czech Transformation: Emerging Patterns of Dependence and Independence, in: Journal for East European Management Studies $6 / 3,239-260$

Clarke, S. (ed.) (1995): Management and Industry in Russia: Formal and Informal Relations in the Period of Transition, Aldershot

Cole, R. E. (1999): Managing Quality Fads: How American Business Learned to Play the Quality Game, New York

Cyr, D.J. (1997): Culture and Control: The Tale of East-West Joint Ventures, in: Management International Review 37/1, 127-144

Cyr, D.J./Schneider, S.C. (1996): Implications for Learning: Human Resource Management in East-West Joint Ventures, in: Organization Studies 17/2, 207-226

Dickie, R.B. (1991): Western Business Should Approach Eastern Europe Mindful of Experience in East Asia, in: California Management Review 33/4, 118-126

Edwards, V./Lee, G. (1999): Models of Management Formation: Implications for Central and Eastern Europe, in: Journal for East European Management Studies 4/4, 292-305

Faust, M. (2002): Consultancies as Actors in Knowledge Arenas: Evidence from Germany, in: Kipping, M./Engwall, L. (ed.): Management Consulting. Emergence and Dynamics of a Knowledge Industry, Oxford-New York, 146-163

Fligstein, N. (1990): The Transformation of Corporate Control, Cambridge, MA-London, England

Fligstein, N. (1996): Markets as Politics: A Political-Cultural Approach to Market Institutions, in: American Sociological Review 61, 656-673

Fligstein, N. (1997): Markets, Politics, and Globalization, Uppsala 
Fligstein, N. (2001): The Architecture of Markets. An Economic Sociology of Twenty-FirstCentury Capitalist Societies, Princeton, N.J.-Oxford

Fey, C.F./Nordahl, C./Zatterstrom, H. (1999): Organizational Culture in Russia: The Secret to Success, in: Business Horizons 42/6, 47-55

Frege, C.M./Taplin, I.M. (1999): Managing Transitions: The Reorganization of Two Clothing Manufacturing Firms in Hungary, in: Organization Studies 20/5, 721-740

Gatian, A.W./Gilbert, K.C. (1996): The Central European Need for Management Training and Advisory Services, in: Multinational Business Review 4/1, 69-76

Gerber, T.P./Hout, M. (1998): More Shock than Therapy: Market Transition, Employment, and Income in Russia 1991-1995, in: American Journal of Sociology 104/1, 1-50

Ginsberg, A./Abrahamson, E. (1991): Champions of Change and Strategic Shifts: The Role of Internal and External Change Advocates, in: Journal of Management Studies 29, 173 190

Grabher, G./Stark, D. (eds.) (1997): Restructuring Networks in Post-Socialism. Legacies, Linkages, and Localities, Oxford

Granovetter, M. (1973): The Strength of Weak Ties, in: American Journal of Sociology 78, 1360-1380

Granovetter, M. (1978): Threshold Models of Collective Behavior, in: American Journal of Sociology, 83, 1420-1443

Hall, Peter A./Soskice D. (eds.) (2001): Varieties of Capitalism. The Institutional Foundations of Comparative Advantage, Oxford-New York

Haunschild, Pamela R. (1993): Interorganizational Imitation: The Impact of Interlocks on Corporate Acquisition Activity, in: Administrative Science Quarterly 38, 564-592

Hausner, J. (ed.) (1997): the Polish transformation from the Perspective of European Integration, Warsaw

Heintz, M. (2002): East European Managers and Western management theories: an ethnographic approach of Romanian service sector enterprises, in: Journal for East European Management Studies Vol 7 No 3, 279-297

Hofstede, G. (1994): Cultural Constraints in Management Theories, in: International Review of Strategic Management 5, 27-48

Holden, N. (2000): Cross-Cultural Management at the Threshold of the New Millenium, in: Journal of Cross-Cultural Competence \& Management 2, 41-71

Hollingsworth, J.R./Boyer, R. (eds.) (1997): Contemporary Capitalism. The Embeddedness of Institutions, Cambridge

Ilieva, S. (1999): Work Attitudes in Transition: some Implications for Management of Organizational Change in Bulgaria, in: Journal for East European Management Studies 4/4, 279-291

Jankowicz, A.D. (1994): The New Journey to Jerusalem: Mission and Meaning in the Managerial Crusade to Eastern Europe, in: Organization Studies 15, 497-507

Jankowicz, A.D. (2001): Limits to Knowledge Transfer: What They Already Know in the Post-Command Economies, in: Journal of East-West Business 7/2, 37-60 
Katz, E. (1960): Communication Research and the Image of Society: Convergence of Two Traditions, in: American Journal of Sociology 65, 435-440

Katz, E./Levin, M.L./Hamilton, H. (1963): Traditions of Research on the Diffusion of Innovation, in: American Sociological Review 28, 237-252

Kieser, A. (2002): Managers as Marionettes ? Using Fashion theories to Explain the Success of Consultancies, in: Kipping, M./Engwall, L. (ed.): Management Consulting. Emergence and Dynamics of a Knowledge Industry, Oxford-New York, 167-183

King, L.P. (2001): Making Markets: A Comparative Study of Postcommunist Managerial Strategies in Central Europe, in: Theory and Society 30/4, 493-538

Kipping, M./Engwall, L. (ed.) (2002): Management Consulting. Emergence and Dynamics of a Knowledge Industry, Oxford-New York

Konecki, K. (1997): The Social Construction of Enterprise Strategies. Consequences of Privatization, in: Jornal of East European Management Studies 2/2, 121-138

Kostera, M. (1995): Differing Managerial Responses to Change in Poland, in: Organization Studies 16/4, 673-697

Kostera, M. (1996): The Modern Crusade: the Missionaries of Management come to Eastern Europe, in : Müller, B. (ed.): A la recherche des certitudes perdues....., Berlin

Kostera, M./Wicha, M. (1996): The „Divided Self“ of Polish State-Owned Enterprises: The Culture of Organizing, in: Organization Studies 17/1, 83-106

Kovach, R.C.jr. (1994/1995): Matching Assumptions to Environment in the Transfer of Management, in: International Studies of Management \& Organization 24/4, 1-13

Lam, A. (1997): Embedded Firms, Embedded Knowledge: Problems of Collaboration and Knowledge Transfer in Global Cooperative Ventures, in: Organization Studies 18, 973-996

Lavigne, M. (1999): The Economics of Transition. From Socialist Economy to Market Economy, $2^{\text {nd }}$ ed., Basingstoke-London

Ledeneva, A.V. (1997): Practices of Exchange and Networking in Russia, in: Soziale Welt $48 / 2,151-170$

Lehrer, M. (2001): Macro-varieties of Capitalism and Micro-varieties of Strategic Management in European Airlines, in: Hall, P. A./Soskice, D. (eds.): Varieties of Capitalism. The Institutional Foundations of Comparative Advantage, Oxford-New York, 361-386

Lenke, S./Goronwy, D. (1996): A Contextual Approach to Management Learning: The Hungarian Case, in: Organization Studies 17/2, 269-290

Lillrank, P. (1995): The Transfer of Management Innovations from Japan, in: Organization Studies 16, 971-989

Lizal, L./Singer, M./Svejnar, J. (1994): Manager Interests, Breakups and Performance of State Enterprises in Transition, Prag: CERGE EI. Working Paper Series 51

Lovell, S./Ledeneva, A.V./Rogachevskii, A. (2000): Bribery and Blat in Russia. Negotiating Reciprocity from the Middle Ages to the 1990s, Basingstoke

Lupton, R.A./Jansen, D.G. (1998): American Business Education in Central Europe: Serving What Ends and for Whom? In: Business Horizons 41/4, 27-33 
Lyles, M.A./Salk, J.E. (1996): Knowledge Acquisition from Foreign Parents in International Joint Ventures: An Empirical Examination in the Hungarian Context, in: Journal of International Business Studies 27/5, 877-903

Lyles, M.A./Carter, N.M./Baird, I.S. (1996): New Ventures in Hungary: The Impact of U.S. Partners, in: Management International Review 36/4, 335-370

Luthans, F./Patrick, R.R./Luthans, B.C. (1995): Doing Business in Central and Eastern Europe: Political, Economic and Cultural Diversity, in: Business Horizons 38/5, 9-16

Makó, C. (2001): Globalization and Organizational Innovation, www.forba.at/files/news/ referate/mako.pdf

Makó, C./Ellingstad, M. (2000): Globalization, FDI and Modernising Management Practices, in: Journal for East European Management Studies Vol 5 No 4, 341-360

Malone, C./Kirk, R.D. (2000): Best Practice Diffusion in a Polish National Investment Fund (NIF): A Comparative Study from an Institutional Theory Perspective, in: Journal for East European Management Studies 5/4, 324-340

Marinov, M.A./Marinova, S. (1998): Investor Strategy Development and Adaptation, in: European Management Journal 16/4, 400-410

Marinov, M.A./Marinova, S. (1999): Foreign Direct Investment Motives and Marketing Strategies in Central and Eastern Europe, in: Journal of East-West Business 5/1-2, 2556

Marinov, M.A./Marinova, S./Watts, G. (1998): Privatization and Company Restructuring in Eastern Europe, in: Journal of East-West Business 4/1-2, 29-46

Martin, R. (1999): Transforming Management in Central and Eastern Europe, Oxford-New York

Mathews, J.A. (2002): Dragon Multinational. A New Model for Global Growth, Oxford-New York 2002

Mazza, C. (1998): The Popularization of Business Knowledge Diffusion: From Academic Knowledge to Popular Culture?, in: Alvarez, J. L. (ed.): The Diffusion and Consumption of Business Knowledge, New York, 164-181

McDonald, K.R. (1993): Why Privatization is not Enough, in: Harvard Business Review 71/3, 49-50

Mense-Petermann, U. (1997): Betriebliche Restrukturierung im Ländervergleich, in: Journal for East European Management Studies 2/2, 173-197

Meschi, P.X./Roger, A. (1994): Cultural Context and Social Effectiveness in International Joint Ventures, in: Management International Review 34/3, 197-215

Meyer, K.E. (2003): Corporate Governance in Transition Economies, in: Journal of Financial Transformation 9, 31-38

Micklethwait, J./Wooldridge, A. (1997): The Witch Doctors, London

Michailova, S./Hollinshead, G. (2001): Western Management Training in the ,New' Europe beyond Ethnocentric Coherence and Polycentric Ambiguity, Paper submitted to the Second International Conference on Critical Management Studies, University of Manchester, UK, June 2001 
Morawski, W. (1998): Systemic Change as Institutional Change: Universal Challenges and Polish Adaptations, in: Polish Sociological Review 3

Morgan, G./Kristensen, P.H./Whitley, R. (eds.) (2001): The Multinational Firm. Organizing Across Institutional and National Divides, Oxford-New York

Müller, B. (ed.) (1996): À la recherche des certitudes perdue, Berlin

Müller, K. (1995): Vom Post-Kommunismus zur Postmodernität? Zur Erklärung sozialen Wandels in Osteuropa, in: Kölner Zeitschrift für Soziologie und Sozialpsychologie $47 / 1,37-64$

Mueller, S.L./Clark, L.D. (1998) : Political-Economic Context and Sensitivity to Equity: Differences between the United States and the Transition Economies of Central and Eastern Europe, in: Academy of Management Journal 41/3, 319-329

Mygind, N. (2001): Enterprise Governance in Transition - A Stakeholder Perspective, in: Acta Oeconomica 51, 315-342

Pastor, J.C./Meindl, J./Hunt, R. (1998): The Quality Virus: Inter-Organizational Contagion in the Adoption of Total Quality Management, in: Alvarez, J.L. (ed.): The Diffusion and Consumption of Business Knowledge, New York, 201-218

Peng, M.W. (2000): Business Strategies in Transition Economies, Thousand Oaks-LondonNew Delhi

Peters, T.J./Waterman, R.H., jr. (1982): In Search of Excellence, New York

Pribova, M./Savitt, R. (1995): Attitudes of Czeck Managers towards Markets and Marketing, in: International Marketing Review 12/5, 60-71

Ralston, D.A./Holt, D.H./Terpstra, R.H./Kai-cheng,Yu (1995): The Impact of Culture and Ideology on Managerial Work Values, in: Academy of Management Journal Special Vol. Best Papers Proceedings 1995, 187-192

Robertson, M./Swan, J./Newell, S. (1996): The Role of Networks in the Diffusion of Technological Innovation, in: Journal of Management Studies 33, 333-359

Robinson, I. (1999): The Dynamics of Change in a Privatised Polish State Owned Enterprise: An Analysis of the Human Resource Management Implications, in: Journal for East European Management Studies 4/1, 28-44

Robinson, I./Tomczak-Stepien, B. (2000): Cultural Transformation at Enterprise Level: Case Study Evidence from Poland, in: Journal for East European Management Studies Vol.5 Nr 2, 130-151

Rogers, E.M. (1995): Diffusion of Innovation, $4^{\text {th }}$ ed., New York

Rogers, E.M./Floyd Shoemaker, F. (1971): Communication of Innovations. A Cross-Cultural Approach, $2^{\text {nd }}$ ed., New York-London

Roney, J. (1997): Cultural Implications of Implementing TQM in Poland, in: Journal of World Business, 32/2, 258-276

Ross, D.N.(1996): The Japanese Model of Capitalism: A Guide to Russia's Marketization ? In: Journal of East-West Business 2/1-2, 93-116

Ross, R.J./Trachte, K.C. (1990): Global Capitalism. The New Leviathan, New York 
Savitt, R. (1998): Evolving Management Practices in the Czech Republic: Restructuring and Market Orientation, in: Journal for East European Management Studies 3/4, 339-354

Shama, A. (1995): From Exploiting to Investing: An Empirical Study of Entry Strategies of U.S. Firms to the Former Soviet Bloc, in: Academy of Management Journal Special Vol. Best Paper Proceedings, 197-200

Soulsby, A./Clark, E. (1996): The Emergence of Post-Communist Management in the Czech Republic, in: Organization Studies 17/2, 227-248

Spenner, K.I./Suhomlinova, O./Thore, S.A./Land, K.C./Jones, D.C. (1998): Strong Legacies and Weak Markets: Bulgarian State-Owned Enterprises during Early Transition 63/4, 599-617

Srubar, I. (1994): Post-Socialist Developments in Central Europe: Variants of the Transformation Process in Central Europe. A Comparative Assessment, in: Zeitschrift für Soziologie 23/3, 198-221

Stokman, F.N./Ziegler, R./Scott, J. (eds.) (1985): Networks of Corporate Power. A Comparative Analysis of Ten Countries, Cambridge-Oxford

Strang, D./Macy, M.W. (2001): In Search of Excellence: Fads, Success Stories, and Adaptive Emulation, in: American Journal of Sociology 107, 147-182

Strang, D./Meyer, J.W. (1993): Institutional Conditions for Diffusion, in: Theory and Society $22,487-511$

Suhomlinova, O. (1999): Constructive Destruction: Transformation of Russian State-Owned Construction Enterprises during Market Transition, in: Organization Studies 20/3, 451484

Svejnar, J. (1996): Enterprises and Workers in the Transition: Economic Evidence, Prag: CERGE EI. Working Papers 96

Swan, J./Newell, S./Robertson, M. (1999): Central Agencies in the Diffusion and Design of Technology: A Comparison of the UK and Sweden, in: Organization Studies 20, $905-$ 931

Sztompka, Piotr (1993): Civilizational Incompetence: The Trap of Post-Communist Societies, in: Zeitschrift für Soziologie 22/2, 85-95

Sztompka, Piotr (1995): Vertrauen: Die fehlende Ressource in der postkommunistischen Gesellschaft, in: Kölner Zeitschrift für Soziologie und Sozialpsychologie 35. Sonderheft, 254-276

Tarde, G. (1890): Les lois de l'imitation, Paris

Thomas, M.J. (1994): Marketing - In Chaos or Transition ? In: European Journal of Marketing 28/3, 55-62

Thomas, S. (1993): The Politics and Economics of Privatization in Central and Eastern Europe, in: Journal of World Business 28/1, 168-178

Tóth, T. (1995): Management-Kooperation und Transfer von Management Know-How in Osteuropa, in: Wirtschaft und Recht in Osteuropa 4, 132-135

Tolbert, P.S./Zucker, L. G. (1983): Institutional Sources of Change in the Formal Structure of Organizations: The Diffusion of Civil Service Reform, in: Administrative Science Quarterly 28, 22-39 
Tucker, L.R./Jain, S.C./Failer, B. (1993): MNC Market Opportunity Analysis of Eastern Europe: An Innovation Perspective, in: Journal of Euromarketing 2/4, 25-44

Vamosi, T.S. (2001): Management between Continuity and Change - a Case Study from Hungary, in: Journal for East European Management Studies 6/2, 121-151

Villinger, R. (1996): Post-Acquisition Managerial Learning in Central East Europe, in: Organization Studies 17/2, 181-206

Vlachoutsicos, C.A./Lawrence, P.R. (1996): How Managerial Learning can Assist Economic Transformation in Russia, in: Organization Studies 17/2, 311-326

Walger, G. (1997): Ein beratungsorientiertes Change-Management Konzept für Unternehmen in Lettland, in: Journal for East European Management Studies 2/1, 54-73

Warhurst, C. (2000): MNCs and the Tranfer and Diffusion of ,Soft ${ }^{\star}$ Technologies: Issues for Central and Eastern Europe, in: Journal for East European Management Studies Vol 5, $\mathrm{Nr} 1,28-45$

Westney, D.E. (1987): Imitation and Innovation. The Transfer of Western Organizational Patterns to Meiji Japan, Cambridge, Mass.- London

Whitley, R. (ed.)(1994): European Business Systems, London

Whitley, R. (2000): Divergent Capitalisms. The Social Structuring and Change of Business Systems, Oxford-New York

Whitley, R. et al. (1996): Trust and Contractual Relations in an Emerging Capitalist Economy: The Changing Trading Relationships of Ten Large Hungarian Enterprises, in: Organization Studies 17/3, 397-420

Whitley, R./Czaban, L. (1998): Institutional Transformation and Enterprise Change in an Emergent Capitalist Economy: The Case of Hungary, in: Organization Studies 19/2, 259-280

Zeitz, G./Mittal, V./McAulay, B. (1999): Distinguishing Adoption and Entrenchment of Management Practices: A Framework for Analysis, in: Organizational Studies 20, 741 776 